\title{
Okul Yılları ve Okul Dışındaki Sosyal İlişsilerin Kadın Liderlerin Liderlik Gelişimindeki Rolü
}

\author{
Doç. Dr. Aydın BALYER* \\ Yıldız Teknik Üniversitesi, Eğitim Fakültesi, İstanbul / Türkiye
}

\section{$\ddot{O} z$}

Okul yılları, insanların bütün eğitim hayatları süresince eğitim kurumlarında geçirdikleri dönem, sosyal ilişkiler ise birbirinden haberdar olan en az iki insan arasında belirli bir süre devam eden, anlamlı ve belirli amaçlar etrafında kurulan sosyal bir bağdır. Bu süreçlerin insan kişiliği ve liderlik gelişiminde erken yaşlardan itibaren önemli bir yer tutması nedeniyle mevcut çalışmanın temel amacı, bu örneklem grubunda yer alan kadın liderlerin okul yılları ve okul dışındaki sosyal ilişkilerinin (âile, çevre vb.) onların liderlik gelişimleri üzerindeki rolünü ortaya çıkarmaktır. Nitel olarak yürütülen bu çalışmada İstanbul ilinde bulunan bazı devlet üniversiteleri ve Millî Eğitim Bakanlığı'na bağlı devlet okullarında hâlen yönetim görevi yapan ve yürüttükleri görevlerde kurumlarının akademik olarak gelişiminde önemli katkılar sağlamış olan seçilmiş 20 kadın liderle yüz yüze görüşmeler gerçekleştirilmiştir. Veriler tümevarımcı analiz yöntemiyle analiz edilmiştir. Araştırmada elde edilen sonuçlar, kadın liderlerin okul yılları ve sosyal ilişkilerinin onların liderlik gelişimlerinde önemli bir role sâhip olduğunu göstermektedir.

Anahtar Kelimeler: Liderlik; Kadın liderler; Okul yılları; Sosyal ilişkiler.

\footnotetext{
* Sorumlu Yazar. $\quad$ Tel: +90212383 $\quad$ E-posta:balyer@yildiz.edu.tr
}

(C) 2016 Kalem Eğitim ve Sağlık Hizmetleri Vakfı. Bütün Hakları Saklıdır. 


\title{
The Role of School Years and Social Relations Outside the School on Woman Leaders' Leadership Development
}

\begin{abstract}
School years is the period when people spend their times throughout their educational lives in their institutions and social relations are the social ties set and continue for some time between at least two people consciously and meaningfully for a certain purpose. As these processes are important in people's life and their leadership development since very early ages, the main concern of this study is to discover the role of school years and their social relations outside the school (family, social environment) on woman leaders' leadership development. In this qualitative study, interviews were conducted with 20 selected women who are currently working as administrators at some public universities and some public schools of Ministry of National Education (MoNE) in Istanbul province and have obtained great successes academically at their institutions. The data were analyzed with inductive method. Results indicate that school years and social relations have an important role in woman leaders' leadership development process.
\end{abstract}

Keywords: Leadership; Woman leaders; School years; Social relations.

\section{Extended Summary}

\section{Purpose}

Management is defined as a process of coordinating human and other resources to reach organizational goals. In this regard, learders are supposed to manage them efficiently. This makes leaders' work more important, because their administrative behaviors and attitudes create great differences in their institutions. Despite its long history, there have been lots of researches conducted to define leaders and their roles and these researches diverse accordingly. In this research scope, dif- 
ferent leadership styles have been defined. If leadership is accepted as a sum of many factors, it is possible to categorize these developmental factors into three groups. These are first effects, parenthood styles and first learning experiences. Findings show that social relations, school years and learning experiences are important determinants of early leadership development (Fine, 2010; Hyvärinen and Uusiautti, 2014) and education is supposed to have an effect in early leadership development (Mitra, 2006; Murphy and Johnson, 2011).

When school years and social relations are concerned in leadership development, Murphy and Johnson (2011) categorize them into two groups as private education and general educational experiences. Education about leadership supports them from the very early years (Matthews, 2004; Myers, Slavin and Southern, 1990). However, school years provide many opportunities for students to practice their leadership (Murphy and Johnson, 2011). These opportunities can be positive social interactions and team work. For example, when a student has an intrinsic leadership ability, school may offer suitable conditions for student to reveal this power.

Lifelong approach in the leadership development gives importance to school years and social relations and they categorize it into three groups. They are sports activities, educational facilities and other practices (Murphy and Johnson, 2011). According to this approach, developing vision, thinking, improving self-efficacy, focusing on success, being entrepreneur, following their rights, being competitive, and being task oriented can be learned at school. Once they are learnt, 
children may use them in their administrative practices (Murphy and Johnson, 2011; Ropers-Huilman, Carwile and Barnett, 2005). These activities help the child improve himself socially as well (Mitra, 2006). As the school offers students cognitive, physical, and social and implementation opportunities, they form students in any case (Kim and Baylor, 2006; Wilson 1995).

School years also offer many opportunities like learning success, failure, struggling, accepting failure, controlling anger, enjoying success, self-evaluation and problem solving skills, developing goals, setting up and sustaining social relations. According to Charbonneau and Nicol (2002) childhood and social activities are important in leadership development. Mayhew, Wolniak and Pascarella (2008) and Antonio (2001) reveal that peer relations have a positive influence on leadership development. Matthews (2004) claims that childhood development, social relations in adolescence period and school years have positive contribution to women's leadership development.

However, woman leadership has not been researched much in Turkey. There are few studies and they mainly focused on the barriers they face in their leadership development. Although most teachers are woman in Turkish educational system, there are less woman administrators (5.07\%) (Boydak and Akpınar, 2002). According to Tan (2002) even though teaching is perceived as a woman profession both in Turkey and in the world, woman are kept away from administrative positions. Therefore, this study aims to determine the role of school years and social relations on woman leaders' leadership development. 
As there are few researches on woman leaders' leadership development in educational administration field, this study may contribute to fulfill this area.

\section{Method}

This study was carried out with a qualitative research design. These kinds of researches are used to gain in-depth knowledge in a study (Denzin and Lincoln, 2005; Marshall and Rossman, 2006). More specifically, the study employed an ethnographic research design in collecting data. Ethnographic designs, as Creswell (2002) described them, "are qualitative research procedures for describing, analyzing, and interpreting a culture-sharing group's shared patterns of behavior, beliefs, and language that develop over time". As such, by using this research design and utilizing in-depth interviews, the study explored "culture-sharing" behaviors, beliefs and language of woman leaders in Turkey. Woman leaders' views were obtained through interviews with semi-structured questions, as recommended by Bogdan and Biklen (2003), to "get the subjects to freely express their thoughts around particular topics. The data were analyzed with content analysis method.

\section{Results}

Results reveal that school years and social relations have important roles in the development of woman leaders' leadership processes. As school offers them different social and educational facilities, woman leaders find these experiences more valuable in the process of their leadership development. Especially, university years contributed to their leadership development. According to another result, as woman 
leaders were academically over the average level, they were more active in social activities, which contributed their leadership developments.

\section{Discussion}

Woman leaders' opinions show that school years and social relations have important roles in their leadership development, especially university years. Another result shows that school years illuminated their future lives with the academic knowledge they obtained from school. A further result reveals that woman leaders of this group were academically far ahead from the others in the same class. This helped them in a positive way. Similar findings were found by Murphy and Johnson (2011). According to them, leadership practices such as coordinating teams, and public speaking are obtained at school. They also add that woman leaders are prepared for their future leadership positions by involving different activities actively at school. Moreover Hyvärinen and Uusiautti (2014) found that school years have contributed woman leaders positively. In addition, Dasgupta and Asgari (2004) claimed that university years are more important determinants in woman leaders' leadership development.

\section{Conclusion}

It can be concluded that school years and social relations have important and positive influence on woman leaders' leadership development. Woman leaders claim that the social relations they encountered have helped them a lot to demonstrate their leadership potential. They also add that since school offers them different social and educa- 
tional facilities, woman leaders find these experiences more valuable in the process of their leadership development. They were also academically over the average level, and this made them more confident and more active in social activities.

\section{Giriş}

Bir meslekî öğrenme toplumu olarak kurgulanan okulların temel özellikleri Özdemir'e göre (2013) okul yöneticilerinin güçlerini, yetkilerini ve kararlarını demokratik bir anlayış çerçevesinde paylaştıkları destekleyici ve paylaşımcı liderlik; okul yöneticileri ve öğretmenlerin, öğrenci öğrenmesine odaklanan okul vizyonunu birlikte geliştirdikleri değerler ve vizyon; öğretmenler ve diğer çalışanların birlikte öğrenmeleri ve öğrendiklerini hayata geçirmeleri anlamına gelen işbirlikçi öğrenme uygulamaları; okul koşullarının ve okulun sâhip olduğu insan kapasitesinin geliştirilmesi ve öğretmenlerin bireysel ve örgütsel kapasiteyi artırmak için birbirlerinin öğretimsel uygulamalarını gözlemleyip dönüt vermeleridir. Bütün bu özellikler okulda paylaşım, işbirliği, öğrenme uygulamaları, destekleyen okul kültürü ve öğretimsel paylaşımların önemini göstermektedir. Bu kapsamda önemli bir görev üstlenen yönetim, örgütsel amaçların gerçekleştirilmesinde insan ve madde kaynaklarının eşgüdümlenmesi olarak tanımlanmaktadır. $\mathrm{Bu}$ nedenle, örgütsel amaçların gerçekleştirilmesi ve etkililiğin sağlanması için örgütte bulunan bütün insan ve madde kaynaklarının iyi bir şekilde yönetilebilmesi gerekmektedir. Örgütlerde bu yönetsel sorumluluğu yerine getirmesi gerekenler de liderlerdir. 


\section{Liderlik}

Yüz yıllık tarihine karşın, liderliğin evrensel bir tanımını ortaya koymak için yürütülen araştırmalar her geçen gün çeşitlenerek devam etmektedir. Liderlik teorileri de liderlik tanımları kadar sık değişmiştir. Liderlik teorileri zaman içinde örgütsel ihtiyaçları karşılamak için evrime uğramıştır (Gündüz ve Doğan, 2009). Bu araştırma çeşitliğinde, farklı liderlik türleri tartışılmakta ve örgütler için en iyi liderlik türü belirlenmeye çalışılmaktadır. Liderlik konusunda farklı tanımlar bulunmaktadır. Bu farklı tanımların üzerinde durdukları ortak bir hususa göre liderlik, grup içerisinde olan, grubu etkileyen ve genel amaçları içeren bir süreçtir (Juuti, 2010; Northouse, 2013; Peele, 2005; Solheim, 2000; Syväjärvi ve Vakkala, 2012; Uusiautti, Syväjärvi, Stenvall, Perttula ve Määttä, 2012; Yukl, 2010). Başaran'a göre (1992) lider, grubun bir üyesi olarak, öteki üyeler üzerinde olumlu etkide bulunan kişidir. Lider, okulda davranış ve değerler arasında dengeyi kuran, kişilerarası ilişkilere odaklanan, bürokrasi yerine, demokrasiyi geliştiren, kontrol etme yerine güçlendirmeyi, yönlendirmeden ziyade etkilemeyi, statüyü sürdürmek yerine risk almayı, durağanlık yerine değişimi destekleyen kişidir (Lombardo ve McCall, 1978; McCall, Lombardo ve Morrison, 1988; Quinn, 1988).

Hacıfazlıoğlu'na göre (2010) yönetim alanyazında zaman zaman yakın anlamda kullanılmasına rağmen yönetici ve lider kavramlarının yüklendikleri anlamlar birbirinden farklıdır. Buna göre yönetici atamayla göreve gelip kurumun mevcut yapısını koruyarak, örgütsel amaçları gerçekleştirmektir. Hâlbuki lider, örgütün amaçları ile bütün 
iş görenlerin ihtiyaçlarını dengeleyerek, onları işbirliği içerisinde amaçlarını gerçekleştirmeye yönlendirmektir (Gümüşeli, 1996). Dolayısıyla bu kapsamda lider, yöneticiden farklı etkileme gücü olan ve örgütlerde fark yaratan kişidir.

Liderlikte geleneksel yaklaşımların 1980'li yılların ortasına kadar etkili olduğu görülmektedir. Bu yaklaşımların ileri sürdügü liderlik özelliği, öğretim programının eksiksiz bir şekilde uygulanmasının sağlanmasıdır. Bu dönemde liderler olarak müdürler, kişisel ve mesleki özellikleri itibariyle genel olarak deneyimli ve öğretme yeterliğini taşıyan kişilerdir (Cavanagh ve Romanoski, 2006).

1970'lerde feminist teori hareketinin etkisiyle artmaya başlayan liderlik ile cinsiyet ilişsisi son otuz yıldır araştırmalara konu olmaktadır. Bu kapsamda Nidiffer (2001) geleneksel liderlik kuramlarını cinsiyet açısından incelemiş, ataerkil toplumlarda güç ve liderliğin, erkeklere atfedilen bir özellik ve ayrıcalık olduğunu ortaya koymuştur. Liderlik rolü açısından erkek egemen yaklaşımlar (Bosak ve Sczesny, 2011; Gidengil ve Everitt, 2003) dikkate alındığında, kadın liderlik rolünün öne çıkarılması çağdaş bir gelişme olarak da görülebilir. Eagly ve Johnson (1990) kadın liderlerin erkek liderlere göre daha farklı bir liderlik yaklaşımı gösterdiklerini ve etkililiklerinin daha farklı değerlendirildiğini vurgulamaktadırlar. $\mathrm{Bu}$ anlamda kadın liderleri kişilerarası ilişkiler odaklı, erkek liderleri ise görev odaklı tanımlamaktadırlar. Yine Amerika'da yürütülen ilk araştırmalarda "kadın liderliği" ve "kadın liderler" kavramları yönetsel görevler ya da liderlik pozisyonlarını ifade etmektedir (Alvesson ve Billing, 1997; Ekonen, 2007; Huy, 
2001; Kuusela, 2010; Rouleau ve Balogun, 2011; Vanhala, 2007, 2011). Bazı araştırmalarda adları bu pozisyonlarda anılsa bile ülke başına kadın liderlerin sayısının hâlâ yeterli ve anlamlı oranda karş1laştırılabilir olmadığı görülmektedir (Davidson ve Burke, 2004; Martelius-Louniala, 2003; Northouse, 2013; Peele, 2005; Vanhala, 2007; Vinnicombe, 2000; Yukl, 2010). Bu durum, kadın liderler konusunda çalışanlar için önemli bir zorluktur.

Liderlikte erkek egemen yaklaşımlar, kadınların daha çok evle ilgili olarak algılandığı için genellikle iş ve âile yaşantıları arasında bir çatışma içerisinde olacaklarını varsayar. Bu varsayım onların örgütlerinde yeterince başarılı olamayacakları algısına neden olabilmekte ve zaman zaman onların liderliklerinin teşvik edilmemesi sonucunu getirebilmektedir. Hâlbuki uygulamada bazı kadın liderlerin erkek liderlere oranla daha başarılı işler yaptıkları da görülmektedir (Hoobler, Wayne ve Lemmon, 2009).

Bazı toplumlar ve bireyler, cinsiyet kalıp yargiları nedeniyle kadınların üst düzey pozisyonlarda yer almaları konusunda bazı ön yargılara sâhiptirler. Bu durum, yer yer kadınların aleyhine bir durumun oluşmasını getirebilmekte ve onların yönetim kademesine yükselmesini engelleyebilmektedir (Dominici, Fried ve Zeger, 2009). Bu yarg1lar, "kadınların erkeklerden farklı olduğunu" ve bu sebeple onların “etkin bir yönetimin gereğini” yerine getiremeyecekleri yönünde bir düşünceye neden olabilmektedir. Diğer bir deyişle, kadınların erkekler kadar yönetsel vasıflara sâhip olmadığı düşüncesine sâhip kültürlerin ve bu yargıların etkisinde kalan erkeklerin tutumları kadınlar aleyhine 
süregelen ve devam eden bu olumsuz durumu devam ettirmektedir (Porat, 1991). Yine bu tip yargılar, kadınların yönetsel pozisyonlara gelmelerini engellemenin dışında, bu pozisyonlarda çalışan kadınların yetkilerini kullanma biçimini de etkilemektedir. Bu yargıların en yoğun olarak görüldüğü alanlardan birisi de eğitim kurumlarıdır (Usluer, 2000). Turan ve Ebiçlioğlu (2002) cinsiyet açısından bakıldığında, eğitim yönetiminin de erkek egemen bir alan olduğu üzerinde durmaktadırlar. Eğitim örgütlerinde üst kademe eğitim yöneticileri arasında kadın liderlerin yok denecek kadar az olması, yönetim alanının erkek egemen bir yapıya sâhip olduğu düşüncesini desteklemektedir.

\section{Kadın Liderlerin Liderlik Gelişimi}

Liderlik, birçok faktörün toplamı olarak kabul edilmektedir (Uusiautti ve Määttä, 2013a, 2013b). Murphy ve Johnson (2011) liderlerin gelişimsel süreçleri ilk etkiler, ebeveynlik stilleri ve ilk öğrenme deneyimleri şeklinde üç kategoriye ayırmaktadırlar. Bu kapsamda erken gelişimsel etkenler, liderlik kimliğini ve öz düzenlemeyle ilgili yapıları oluşturur. Bu bakış açısına göre lider kimliğinin erken oluşumu, liderlik beceri gelişiminin temelidir (Lord ve Hall, 2005). Eğitimin de liderlik gelişimini erken yaşlardan itibaren etkilemesi beklenir (Mitra, 2006; Murphy ve Johnson, 2011). Ancak alanyazında bu sürecin ve etkilerinin yeterince araştırılmadığı görülmektedir. $\mathrm{Bu}$ konudaki sınırlı sayıdaki çalışma da çoklukla metodolojik, kaynak taraması yöntemiyle ve özel yetenekli kişiler üzerinde yürütülmüştür (Charbonneau ve Nicol, 2002; Dhuey ve Lipscomb, 2008; Marlene, 2009; Matthews, 2004; Mozghan, Parivash, Nadergholi ve Jowkar, 
2011; Zacharatos, Barling ve Kelloway, 2000; Zeldin ve Petrokubi, 2006). Bu yöntemsel yaklaşımların bu şekliyle kadın liderliğinin gelişimine dâir sınırlı bir bakış açısı ortaya koyacağı değerlendirilebilir. Murphy ve Johnson (2011) kadın liderlerin liderlik gelişiminde okul yılları ve sosyal ilişsiler diye ikiye ayırmaktadır. Bu konuda yürütülen çalışmalardan elde edilen bulgular, gerek sosyal ilişkiler gerekse de okul yıllarının erken liderlik gelişiminde belirleyici olduğunu ortaya koymaktadır (Fine, 2010; Hyvärinen ve Uusiautti, 2014).

\section{Kadın Liderlerin Gelişiminde Okul Yıllarının Rolü}

Okul yılları, insanların bütün eğitim hayatları süresince eğitim kurumlarında geçirdikleri dönemdir. Bu dönemde öğrenciler, sosyal kazanımlar elde etmelerinin yanı sıra akademik olarak gelişmelerinin temelini oluştururlar. Öğrenciler, okul yıllarında elde ettikleri akademik birikimler sayesinde kendilerini gelecekte bazı pozisyonlara taş1yacak donanıma sâhip olurlar. Okul yıllarında bazı öğrenciler akademik olarak öne çıkarken bazıları daha fazla sosyal olarak bazen de her ikisinde gelişme kaydederler.

Murphy ve Johnson (2011) okul yıllarının kadın liderlerin liderlik gelişimi üzerindeki etkilerine dikkat çekmekte ve bu etkileri özel eğitim ve genel eğitim deneyimleri şeklinde iki gruba ayırmaktadırlar. $\mathrm{Bu}$ kapsamda özel eğitimin, liderlere erken yaşlardan itibaren önemli bir destek sağladığı değerlendirilmektedir (Matthews, 2004; Myers, Slavin ve Southern, 1990; Schneider, Paul, White ve Holcombe, 1999). Okul yılları, öğrencilere liderliklerini uygulamaları bakımından önemli fırsatlar sunduğu için onların liderlik gelişimleri üzerinde değerli katkılar 
sağlamaktadır. Bu firsatlar, öğrenci kulüpleri, değişik etkileşimler, takım çalışması ile yürütülen etkinlikler ve bireylerin geçirdikleri olumlu sosyalleşme yaşantılardır. Okul yıllarında sağlanan bu firsatların, öğrencilerin aynı zamanda diğer becerilerinin de ortaya çıkmasına olanak sağladığı vurgulanmaktadır. Söz gelimi, bir öğrencinin içsel bir liderlik özelliğine sâhip olduğu düşünüldüğünde, bunun ortaya çıkabileceği firsatlar sağlanmazsa daha sonraki merhaleleri beklemek gerekmektedir (Murphy ve Johnson, 2011).

Liderlik gelişiminde hayat boyu yaklaşım da okul yıllarına ayrı bir önem verir. Bu yaklaşıma göre okul yıllarındaki öğrenme deneyimleri spor etkinlikleri, eğitim etkinlikleri ve diğer uygulama etkinlikleri olarak üç kategoriye ayrılır. Bu yaklaşıma göre vizyon geliştirme, düşünme, öz yeterlik geliştirme, kazanmaya odaklanma, girişimci olma, kendi çıkarını gözetme, yarışmacı olma ve görev odaklı olma gibi birçok liderlik becerileri okul yıllarında kazanılır. Öğrenciler bu kazanımlarını daha sonraki yıllarda yönetim uygulamalarında kullanırlar (Day, 2000, 2011; Murphy ve Johnson, 2011; Ropers-Huilman, Carwile ve Barnett, 2005; Onay, 2014). Bu yaklaşıma göre aslında eğitim süreçleri ve spor etkinlikleri çocuklarda değişik yollarla liderlik özelliklerinin gelişimine yardımcı olmakta ve okulda kendini bir şekilde ifade edebilen birisinin liderlik gelişimi hızlanmaktadır (Mitra, 2006).

Diğer bir bakış açısına göre okullar insanlara hayat için zihinsel, fiziksel, sosyal öğrenme ve uygulama alanları sunmaktadırlar (Kim ve Baylor, 2006; Wilson 1995). Bu kapsamda okul, çocukluktan itibaren 
insanın iyi ya da kötü şekillenmesini sağlamaktadır. Okul yılları, bireylerin başarıları, başarısızlıkları, değişik fırsatlar yakalaması ve bunları değerlendirmesine olanak sağladığı için ayrıca önemlidir. Yine okul öğrencilere zorluklarla mücadele etme, başarısızlığı kabul etme, öfkeyi kontrol etme, başarıdan keyif alma, kendini değerlendirme, problem çözme, hedef geliştirme ve sosyal ilişkileri nasıl kuracağını ve sürdüreceğine dâir becerileri geliştirmesine yönelik firsatlar sağlar.

\section{Kadın Liderlerin Gelişiminde Okul Dışındaki Sosyal İlişkilerin Rolü}

Sosyal ilişkiler, birbirinden haberdar olan en az iki insan arasında belirli bir süre devam eden, anlamlı ve belirli amaçlar etrafında kurulan sosyal bir bağdır (Barker, 1999). Bu kapsamda kadın liderlerin sözü edilen sosyal ilişkileri âile, çevre ve okulda yaşadıklarıdır. Âile, çevre ve okulun destekleyici davranışları çocukların bazı becerilerini geliştirmelerine neden olabilirken tam tersi davranışların, onların sosyal olarak yetersiz kalmalarına ve kendilerini ifade edememelerine neden olabilmektedir. Âile ve çevre gibi öğrencilerin okulda yaşadıkları sosyal ilişkilerin onların mevcut ve gelecek hayatlarını önemli oranda belirlediği kabul edilmektedir. Aynı zamanda okul da öğrencilerin sosyal gelişimine kaynaklık eden önemli bir yerdir. $\mathrm{Bu}$ anlamda çekingen, sosyal ilişkiler geliştiremeyen bireylerin okulda yaşadıkları bir takım sosyal ilişkiler yoluyla sosyalleştikleri ve farklı becerilerinin öne çıktığı gözlemlenmektedir.

Bir görüşe göre âile, ergenlik gelişimi ve iyi olumlu iş deneyimleri gibi sosyal ilişkiler liderlik gelişiminde önemlidir (Snyder ve Lo- 
pez, 2002). Bu kapsamda yürütülen birçok araştırma, sosyal insan özellikleri ve akran ilişkilerinin, liderlik gelişimlerinde olumlu katkısını ortaya koymaktadır. Buna göre Charbonneau ve Nicol (2002), çocukluk ve ergenlikteki sosyal etkinlikler ve deneyimlerin liderlik gelişimindeki olumlu etkisine değinmektedirler. Diğer bir çalışmada Berscheid (2006) insan davranışını inceleyen herhangi bir bilim alanının, insan davranışlarının insan ilişkilerinden etkilendiği gerçeğini göz önünde bulundurması gerektiğini belirtmektedir. Mayhew, Wolniak ve Pascarella (2008) ve Antonio'ya göre ise (2001), farklı akran ilişkileri liderlik gelişimlerine olumlu bir katkı sunmaktadır. Yine Matthews (2004), liderliğin yetenekli çocuklarda özel eğitimle geliştirilebileceğini ortaya koymaktadır. Ona göre bu yönde bir eğitim almamış ve çalışma yöntemleri birbirinden farklı olan kadın liderlerin liderlik gelişiminde çocukluk, ergenlik dönemindeki sosyal ilişkiler büyük bir fark yaratmaktadır. Hoppe ve Reinelt (2010) liderlik gelişiminde sosyal ilişkilerin lider adaylarının gelişiminde sundukları destek ve bireysel önerilerle onların liderlik gelişimlerinde önemli katkılar sağlamaktadır. Yine Graen ve Uhl-Bien (1995) ve Uhl-Bien (2006)'e göre sosyal ilişkilerde karşılıklı güven, saygı ve anlayış kadınların liderlik gelişiminde etkili olmaktadır. Ross'a göre (2015) sosyal ilişkiler her ne kadar da liderliğin garantisi olmasa da bu ilişkiler olmadan liderlik başlayamaz.

Kadın liderlerin liderlik gelişimi konusu, Türk eğitim sisteminde de yeterince ele alınmış bir konu değildir. Yürütülen sınırlı sayıdaki çalışma da çoklukla kadın yöneticilerin liderlik ve yönetsel becerileri 
ya da liderliklerini engelleyen hususlar üzerinde yoğunlaşmıştır (Turan ve Ebiçlioğlu, 2002). Eğitim yönetiminde de atama ve yükseltmeyle ilgili herhangi bir hukuksal engel olmamasına ve en az erkek meslektaşları kadar iyi eğitim almış olmalarına rağmen kadınların eğitim yönetiminde üst kademelere gelemedikleri görülmektedir (Çelikten, 2004). Gerçi zaman içerisinde kadın yönetici sayısında her ne kadar da bir artış gözlemlense de bu durum yönetimde kadınların temsili açısından büyük bir sorundur. 2002-2003 öğretim yılı verilerine göre okullarda yönetim kademelerinde bulunan kadın ve erkek yönetici sayıları arasında uçurum sayılabilecek farklar vardır. Buna göre okullardaki erkek müdürler \%94.73'lük bir oranda iken, kadın müdürler ancak \% 5.27'lik bir orana sâhiptir (Boydak ve Akpınar, 2002; Ergin ve Çınkır, 2005). 2015 yılı itibariyle öğretmenlerin oranı \%55 iken okul yöneticilerinin sadece \%11'i kadındır. Buna göre 62 bin 333 okul yöneticisinden sadece 6 bin 701'i kadın ve üst yönetimlere çıktıkça sayı daha da azalmaktadır. Öyle ki 81 il millî eğitim müdürü içerisinde sadece bir ve 718 ilçe millî eğitim müdüründen sadece 3'ü kadındır. Yine 255 il millî eğitim müdürü yardımcısından 8'i kadın iken onlar da vekâleten görev yapmaktadırlar (MEB, 2015). Tan’a göre (2002) Türkiye ve dünyada öğretmenlik bir kadın mesleği olarak algılanmasına karşılık eğitim yönetiminden dışlanmıştır. Öyle ki Aydın'a göre (2009) kadınların okul yönetiminde yer almasının tarihinin 1871-72 yıllarına kadar uzanmasına karşın, Türkiye'de ilçe millî eğitim müdürü olarak ilk defa bir kadının atanması 1968, il millî eğitim müdürlüğüne bir kadının atanması 1990 yılında gerçekleşmiştir. Arıkan ve Yıldırım’a göre (1993) kadınların üst yönetim kadrolarında yer almamalarını, âile 
kurumunu ve toplumsal cinsiyet rollerini ilgilendiren normlar ve değerlerdeki yeterli düzeyde ve hızda gelişme olmamasına bağlamaktadırlar. Çiçek-Sağlam ve Bostancı (2012) kadınların yönetim pozisyonlarına gelme sürecinde hukuksal bir engel olmamasına rağmen, âiledeki görev ve sorumluluklarının fazlalığı, kadının toplumsal konumuna ilişkin geleneksel bakış açısı ve toplumun erkek egemen yapısı sosyal olgulara bağlamaktadırlar. Thompson'a göre (2003) erkek öğretmenlerin, yönetici olmaları gerekliliğinin vurgulandığı toplumsal norm ve yargılar, okul gibi formel örgütlerde yeniden üretilmekte ve muhafaza edilmektedir. Sonuç olarak gerek dünyada gerekse de ülkemizde kadın liderler bakımından durum iç açıcı değildir.

$\mathrm{Bu}$ nedenle mevcut araştırmanın temel amacı bu örneklem grubunda yer alan kadın liderlerin okul yılları ve okul dışındaki sosyal ilişkilerinin (âile, sosyal çevre vb.) liderlik gelişimleri üzerindeki rolünü ortaya çıkarmaktır. Eğitim yönetimi alanında kadın liderlerin liderliklerinin gelişimi konusunda yürütülen çalışmaların sınırlı olduğu düşünüldüğünde, mevcut çalışmanın bu eksikliğin giderilmesine katkı sunabileceği değerlendirilmektedir.

\section{Yöntem}

Mevcut araştırmanın temel amacı kadın liderlerin liderlik gelişimlerini etkileyen faktörleri ortaya çıkartmaktır. Bu kapsamda onların okul yılları ve okul dışındaki sosyal ilişkilerinin (âile, sosyal çevre vb.) liderlik gelişimleri üzerindeki rolü belirlenmeye çalışılmaktadır. $\mathrm{Bu}$ amaçla bu çalışmada nitel araştırma yöntemlerinden fenomonolojik araştırma deseni kullanılmıştır. Bu tür araştırmalar çalışma grubunda 
yer alan katılımcıların yarı yapılandırılmış sorulara dâir fikirlerini yazılı ya da sözlü olarak derinlemesine yansitabilmelerine olanak sağlamaktadır. Diğer bir ifadeyle bu tür araştırmaların amacı, olay ve olguların altında yatan gerçekleri ya da anlamları ortaya çıkarmak ve bir konu hakkında derinlemesine bilgi elde etmektir (Denzin ve Lincoln, 2005; Marshall ve Rossman, 2006). Creswell (2002, s.481) nitel araştırmaların "bir durumu tasvir etme, analiz etme ve bir grup ya da kişilerin davranış ve inançlarını yorumlama" konusunda derinlemesine bilgi sağladığını belirtmektedir. Aslında, bu yöntemi kullanarak ve derinlemesine yapılan görüşmelerle, bu çalışma kadın liderlerin bu konudaki "kültür, paylaşım, inançlar, davranışlar ve dilinin" keşfedilmesini sağlamış olur. Burada esas itibariyle ortaya çıkartılması amaçlanan durum, kadın liderlerin okul yılları ve sosyal ilişkilerinin onların liderlik gelişimlerindeki rolüne dâir görüşleridir. Bogdan ve Biklen (2003), bu görüşme yöntemiyle katılımcıların belirli konular hakkındaki görüşlerini özgürce açılayabileceklerini belirtmektedirler. Bu teknikte görüşmecilerin rahatlamaları sağlanır (Kerkhof, 2006).

$\mathrm{Bu}$ tür araştırmalarda görüşmenin temel boyutlarını; görüşme formunun hazırlanması, test edilmesi, görüşmelerin organize edilmesi, hazırlıkların yapılması ve görüşmelerin gerçekleştirilmesi oluşturur. Görüşmeye yön veren form farklı özellikler taşıyabilir. Bununla birlikte, görüşme formunun hazırlanmasında dikkate alınması gereken bazı ilkeler vardır (Yıldırım ve Şimşek, 2003). Yıldırım ve Şimşek’e göre (2003) görüşmede sorulacak soruların görüşülen birey tarafından kolayca anlaşılabilmesi için bu soruların mümkün olduğunca açık ve 
belirgin bir biçimde ifade edilmesi, hazırlanan soruların genel ve soyut olmaması, araştırmacının soruları mümkün olduğunca görüşülen bireyin deneyimlerine göre düzenlemesi gerekir. Bu kapsamda yine, araştırmacı, açık uçlu soruları, önceden kestirilebilir ve kısa yanıtlara neden olabilecek soru türlerinden oluşturmamalıdır. Ayrıntılı konuşmayı teşvik eden "nasıl", "neden” ve "ne" türü sorular sorulmalıdır. Bu arada araştırmacı ipuçları sunmak dışında, verilen yanıtları yönlendirici tepkilerden kaçınmalı ve sorularını yansız bir dille ifade etmelidir. Yine görüşme formu hazırlanırken ve sorular düzenlenirken görüşmeye, güven oluşturucu bir giriş hazırlanmalı ve bireysel bilgilere âit sorular başta ya da sonda sorulmalıdır. Bu çalışmada temel olarak şu soruların yanıtı bulunmaya çalışılmıştır:

1. Okul dışındaki sosyal ilişkilerin kadın liderlerin liderlik gelişimleri üzerindeki rolü nedir?

2. Okul yıllarının kadın liderlerin liderlik gelişimleri üzerindeki rolü nedir?

\section{Çalışma Grubu}

$\mathrm{Bu}$ araştırmanın çalışma grubunu, 2015-2016 eğitim öğretim y1lında İstanbul ili Beşiktaş ve Esenler ilçelerinde bulunan devlet üniversitesinde çeşitli birimlerde yöneticilik görevinde bulunan amaçlı örneklem yöntemiyle seçilmiş 10 kadın lider ve Kadıköy ilçesinde devlet okullarında görev yapan 10 kadın lider oluşturmaktadır. Buna göre, katılımcıların 8'i lisans, 12'si lisansüstü eğitim almışlardır. Yaş değişkeni bakımından değerlendirildiğinde, katılımcıların, 5’i 31-40, 8'i 41-50, 7'si 51-60 yaş arasındadır. Yöneticilik kıdemleri bakımından 
değerlendirildiğinde katılımcıların 5'i 6-10 yıl, 5'i 11-15 yıl, 6'sı 16-20 yıl arası ve 4'ü de 21 yıl ve üzeri kıdeme sâhiptirler. Yine katılımcıların 10’u yükseköğretim kurumlarında yönetici ve 10'u okul müdürüdür. Katılımcılardan 2'si dekan, 4'ü bölüm başkanı, 2'si yüksekokul müdürü ve 2'si enstitü müdürüdür. MEB okullarında müdürlük yapan liderin 4'ü lise müdürü, 3'ü ortaokul müdürü ve 3 tanesi de ilkokul müdürüdür. Amaçlı örneklem yöntemi, belirli bir grup katılımcıyı incelemeyi amaçlar ve araştırmacının katılımcıların evreni temsil edebilmesi yönünde ön bir bilgiye sâhip olmasıdır (Bailey, 1994). Bu yolla, hedef kitle hakkında kapsamlı bir bilgi edinilmesi amaçlanır. Mevcut araştırma kapsamında görüşülen kadın liderler, görev yaptıkları dönemde okullarında liderlik becerileriyle, vizyoner tutumları, okul misyonunun yerine getirilmesi yönünde gösterdikleri çabalar, yüksek akademik standartlar geliştirmeleri, öğretim zamanını korumaya çalışmaları ve öğretmenleri meslekî olarak gelişme yönünde teşvik etme gibi davranışlarıyla kurumlarında ciddi bir değişim ve dönüşüm gerçekleştirmiş olmaları nedeniyle seçilmişlerdir. Yine gerek yükseköğretim kurumları gerekse de MEB okul yöneticilerinin birlikte alınmasının nedeni, kadın liderlerin farklı yönetim geleneklerine sâhip kurumlardaki yönetim deneyimlerine dair zengin bir bakış açısı kazandıracă̆ının değerlendirilmesidir.

\section{Verilerin Toplanması}

Bu araştırmada veriler yarı yapılandırılmış görüşme olarak (yüz yüze) adlandırılan “dağarcık ağ” (repertory grid) tekniği kullanılarak toplanmıştır. Mevcut çalışmada veriler şu yol izlenerek toplanmıştır: 
İlk olarak söz konusu liderlerle yüz yüze randevu alınarak araştırmanın amacı anlatılmış ve gönüllü olarak bu araştırma sürecinde yer almak isteyip istemedikleri sorulmuştur. Katılımcılara, elde edilecek verilerin güvenirliği, bilgilerin saklı tutulacağı ve aynı zamanda katılımcıların kimliklerinin gizli tutulacağı ve araştırmanın herhangi bir yerinde kendilerinin ya da kurumlarının isimlerinin geçmeyeceğine dâir güvence verilmiştir. Bu kapsamda 20 lider araştırmaya gönüllü olarak katılacaklarını bildirmişlerdir. İkinci olarak, görüşmeyi kabul eden katılımcılarla ortak görüşme günleri belirlenmiş ve o tarihlerde kendileriyle görüşülmüştür. Görüşmeler hem elektronik olarak kayıt altına alınmış hem de el yazısıyla not edilmiştir. Katılımcılarla tek tek olmak üzere birer defa görüşülmüş ve bu görüşmelerin her biri yaklaşık 1-1,5 saat arası sürmüştür.

\section{Verilerin Analizi}

Araştırma kapsamında elde edilen verilerin çözümlenmesinde içerik analizi türlerinden tümevarımcı analiz kullanılmıştır. $\mathrm{Bu}$ tür analizler genellikle bir konu üzerinde toplanan benzer verilerin bir araya getirilmesi, analiz edilmesi ve yorumlanmasında kullanılır (Büyüköztürk, Kılıç-Çakmak, Akgün, Karadeniz ve Demirel, 2008; Mayring, 2000; Miles ve Huberman, 1994; Yıldırım ve Şimşek, 2003). Bu araştırma verilerinin analizi üç merhalede gerçekleştirilmiştir. Birinci merhalede ses kaydı olarak elde edilmiş veriler yazılı olarak elde edilen verilerle karşılaştırılmıştır. İkinci merhalede, araştırmacı ile nitel araştırma konusunda deneyimli bir başka öğretim üyesi ayrı ayrı yazılı verileri kodlamışlardır. Araştırmacı ve uzman öğretim üyesi tarafından 
yapılan kodlamalarda uyuşum gösteren kodlar temalara ulaşmada temele alınmıştır. Araştırma verilerinin analizinde ve modelleştirilmesinde “QSR NVivo 8”den yararlanılmıştır. Bu kapsamda yararlanılan uzman görüşleri ve modelleştirme sonucunda daha önce belirtilen iki tema oluşturulmuştur. $\mathrm{Bu}$ anlamda ilk ana tema "Sosyal İlişkilerin Kadın Liderlerin Liderlik Gelişimindeki Rolü”, ikinci tema ise "Okul Yıllarının Kadın Liderlerin Liderlik Gelişimindeki Rolü” olarak belirlenmiştir.

$\mathrm{Bu}$ analiz sürecinde ilk adım, veri organizasyon sürecidir (Bogdan ve Biklen, 2003). Görüşme sonucunda elde edilen veriler, soru bazında ayrı ayrı analiz edilmiştir. Her soruya ilişkin verilen yanıtlar öncelikle, kendi içinde anlamlı bölümlere ayrılmış ve her bölüm kavramsal olarak ne anlam ifade ettiği belirlendikten sonra isimlendirilerek kodlanmıştır. Verilerin organize edilmesi ve analiz edilmesi sürecinde sürekli karşılaştırmalı analiz (Glaser, 1992) yöntemi kullanılmıştır. Bu yaklaşımın en önemli özelliklerinden biri, verilerin toplanması ve analizin birlikte yürütülmesidir. Yine bu yöntem kategorilerin doygunluğu ve teorinin ortaya çıkışıyla sonuçlanabilir. Bu kapsamda yeni teorilerin ortaya çıkması sürekli analiz, veri toplama ve kodlamayla ilgili iki katı güvenlik sağlar (Bogdan ve Biklen, 2003; Glaser, 1992). Bu yöntemde her bir veri takımı (görüşme kayıtları) anahtar kavramlar, tekrar eden olay ve aktivitelere dâir temaların ortaya çıkartılması ve onlara odaklanılmasını sağlamak amacıyla yeniden gözden geçirilir. Her bir katılımcıya âit veriler doğrulayıcı ve çelişen ifadeler bakımından araştırma sorusu ya da alt soruları tatmin edici bir şekilde tümünü kapsayana 
kadar defalarca gözden geçirilir. Verileri organize ederken, araştırmacı ifadelerin doğruluğunu onaylamak için görüşme esnasında tutulan kayıtları ve notları gözden geçirir ve dinler. Bu aynı zamanda kategorilere ayırma, kodlama, verilerin mekanik olarak sınıflandırılması ve bu kodlama kategorisi içerisinde analiz edilmesi anlamına gelmektedir. Aynı zamanda bu görüşmede ortaya çıkan yeni temalar varsa, onlar da kodlanır ve daha sonra görüşme kayıtlarında tekrar eden temalara göre gruplandirılır (Bogdan ve Biklen, 2003). Bu kapsamda her bir kat1lımcıdan elde edilen veriler "liderlerin okul yılları ve sosyal ilişkileri" faktörleri konusundaki görüşleri göz önünde bulundurularak ayrı ayrı kodlanmıştır.

İkinci merhalede, aynı kavramsal boyutta kodlanan ifadeler anlamlı ve mantıklı bir biçimde bir araya getirilmiştir. Üçüncü merhalede, verilerin kolay, anlaşı1ır ve okunabilir bir dil ile tanımlanmasına ve gereksiz tekrarlardan kaçınılmasına dikkat edilmiştir. Son merhalede, tanımlanan bulgular açıklanmış ve birbirleriyle ilişkilendirilmiş ve anlamlandırılarak neden sonuç ilişkisi kurulmaya çalışılmıştır. Okul yöneticilerinin görüşleri Kadın Lider 1, Kadın Lider 2 ve Kadın Lider 3... şeklinde kodlanarak verilmiştir.

\section{Geçerlik ve güvenirlik}

Mevcut araştırmanın geçerliği ve güvenirliğinin sağlanması için bazı önlemler alınmıştır. Nitel araştırmada geçerlik, bilimsel bulguların doğruluğu; güvenirlik ise, bilimsel bulguların tekrarlanabilirliği ile ilgilidir (Yıldırım ve Şimşek, 2003). Araştırmanın iç geçerliğini (inandırıcılığını) artırmak için görüşme formu geliştirilirken ilgili 
alanyazın incelemesi sonucunda konu ile ilgili bir kavramsal bir çerçeve oluşturulmuştur. Görüşme sonrası kişilerin söyledikleri yazılı hâle dönüştürülmüş ve bu metin ilgili kişilere tekrar gönderilerek kontrol etmeleri istenmiş, böylece katılımcı teyidi alınmıştır. Ayrıca yapılan içerik analizinde temalar, ilgili kavramları kapsayacak kadar geniş ve ilgisiz kavramları dışarıda bırakacak kadar dar kapsamda belirlenmeye çalışılmıştır. Bu temalar ve temaları oluşturan alt temaların kendi aralarındaki ilişkisi ile her bir temanın diğerleriyle ilişkisi kontrol edilerek bütünlük sağlanmıştır. Araştırmanın dış geçerliğini (aktarılabilirliğini) artırmak için araştırma süreci ve bu süreçte yapılanlar ayrıntılı bir şekilde açıklanmaya çalışılmıştır. Bu bağlamda, araştırmanın modeli, çalışma grubu, veri toplama aracı, veri toplama süreci, verilerin çözümlenmesi ve yorumlanması ayrıntılı bir biçimde tanımlanmıştır.

Araştırmanın iç güvenirliğini (tutarlığını) artırmak için bulguların bir kısmı da doğrudan verilmiştir. Ayrıca görüşmede elde edilen veriler üzerinde araştırmacı ve nitel araştırma konusunda deneyimli bir öğretim üyesi ayrı ayrı kodlamalar yapmış ve kodlamalar karşılaştırılarak tutarlık oranı hesaplanmıştır. Güvenirlik için her iki araştırmacı tarafından yapılan kodlamalar üzerinde Güvenirlik=Görüş Birliği/Görüş Birliği + Görüş Ayrılığg x 100 formülü uygulanmıştır (Miles ve Huberman, 1994). İki kodlayıcı arasında uyuşum yüzdesi \%90 olarak hesaplanmıştır. Bu kapsamda uyuşum yüzdesinin \%70 ya da daha üstü olması yeterli görüldüğünden veri analizi açısından güvenirlik sağlanmıştır. Dördüncü ve son olarak, araştırmanın dış güvenirliğini (teyit 
edilebilirliğini) artırmak için araştırmacı, süreçte yapılanları ayrıntılı bir biçimde tanımlamıştır.

$\mathrm{Bu}$ görüşmelerin yürütülmesi sürecinde araştırmacı, kişileri belirli fikirler doğrultusunda yönlendirmeden görüşmeleri yürüten, soruları soran ve bu sorulara verilen yanıtları kayıt altına alan, görüşmeleri plânlayan, kolaylaştıran ve dinleyen bir rol üstlenmiştir. Sorular içerik geçerliliğinin kontrol edilmesi bakımından dört alan uzmanına incelettirilmiş ve bu uzman görüşlerinden elde edilen geribildirimlerden yola çıkılarak son şekli verilmiştir. Buna ilaveten araştırmanın güvenirliği, katılımcıların sorulara verdikleri yanıtlar ve kimlik bilgileriyle ilgili bilgilerin gizli tutulacağı güvencesi verilerek sağlanmıştır. Görüşmeler, katılımcıların farklı güç ilişkilerinden etkilenmelerinin önüne geçilmesi bakımından okul dışında ortak olarak belirlenen yerlerde yürütülmüştür.

\section{Araştırmanın Sınırlılıkları}

Diğer bir yandan, bu araştırmanın bir takım sınırlılıkları vardır. Bunlardan birincisi, bu araştırmaya katılan kadın liderler gönüllülerden oluşmaktadır. Bu katılımcıların, diğer üniversite ve okullarda görev yapan meslektaşlarını tam olarak temsil imkânı bulunmamaktadır. Bu nedenle, bu sonuçlar bu çalışma grubunun görüşleriyle sınırlıdır ve bunlardan yapılacak çıkarımlar bu araştırma grubunu temsil etmektedir. Bu sonuçlardan yola çıkarak nicel araştırmalarda olduğu gibi evrene dâir genellemeler ya da çıkarımlarda bulunurken dikkatli davranmak gerekmektedir. İkinci olarak, araştırmacı veri analizinin ana unsurudur. Yapılan analizler, çıkarımlar, yorumlar ve sonuçlar araş- 
tırmacinın verilerle ve konu alanı ve sosyal alandaki durumuna dayanmaktadır ve aynı verilerle farklı bir araştırmacı farklı çıkarımlarda bulunabilir (Bogdan ve Biklen, 2003; Creswell, 2002). Bu nedenle, teoriye dayalı araştırma yorumları araştırmanın güçlü yanını oluşturduğu kadar sınırlılıklarını da ortaya koymaktadır.

\section{Bulgular}

Kadın liderlerin sosyal ilişkileri ve okul yıllarının onların liderlik gelişimleri üzerindeki rolünün ortaya çıkartılması amacıyla yürütülen bu çalışmada bazı sonuçlara ulaşılmıştır. Bu bölümde bu sonuçlara yer verilmektedir.

\section{Kadın Liderlerin Liderlik Gelişimleri Sürecinde Sosyal İlişkilerin Rolü}

Tablo 1'de kadın liderlerin sosyal ilişkileri ve liderlik gelişimleriyle ilgili ortaya çıkan ana tema ve alt temalara yer verilmiştir.

Tablo 1. Kadın Liderlerin Sosyal İlişkileri ve Liderlik Gelişimleriyle İlgili Ortaya Çıkan Ana Tema ve Alt Temalar

\begin{tabular}{llll}
\hline Ana Tema & Alt Temalar & f & $\mathbf{\%}$ \\
\hline Sosyal & Arkadaşlık ve sosyal etkinliklerin rolü & 6 & 30 \\
İlişkileri ve & Diğerlerini yönlendirme & 4 & 20 \\
Kadın & Yeni sosyal ortamlar geliştirme & 4 & 20 \\
Liderlerin & Sosyal etkinliklerde sürekli ön planda olmak & 4 & 20 \\
Liderlik & 2 & 10 \\
Gelişimleri & Yaratıcı fikirler geliştirme & 20 & 100 \\
Toplam & & & \\
\hline
\end{tabular}

Araştırmanın bu kısmında sosyal ilişkilerin kadın liderlerin liderlik gelişimindeki rolüyle ilgili katılımcı görüşlerine yer verilmiştir. 
Bu konuda değerlendirme yapan bir kadın lider şunları söylemektedir: “Okulda olmayı hep sevdim; çünkü arkadaşlarımla orada buluşuyordum. Derslerde arka sıralarda otururdum ve çok sıkıcı değildim. Okul ve dersler önemli değildi; ancak arkadaşlarım, atmosfer ve okuldaki etkinlikler önemliydi. Sosyal olarak onları etkilemek hoşuma gidiyor$d u . "$ (Kadın Lider 1). Bu kadın liderin okulu farklı ve çekici bir sosyal ilişkiler ortamı olarak gördüğü anlaşılmaktadır. Yine bu anlamda söz konusu lider okulu akademik yanından ziyâde, sosyal ilişkiler yönüyle daha çekici bulmaktadır. Diğer bir lider:

Daima diğerlerini olaya katardım. Şüphesiz zor bir şeyle karşllaşırsam diğerleri beni izlerdi. Daima onları bastıracak şeyler yapardım. Birisi bir şey söylerse ben iki katını söylerdim. Aslında pek iyi bir şey olduğu söylenemez; ama öyleydim. Bir yere gidilecek olsa bana sorulurdu. Bir lider olarak doğduğuma inantyorum. Çocukluğumdan beri şef benim. (Kadın Lider 2)

$\mathrm{Bu}$ şekilde bir değerlendirmeden kadın liderin diğerleri üzerinde bir etkisi olduğu ve bu ilişkiler ağını da bu etki yoluyla yaşayarak liderlik becerilerini güçlendirdiği anlaşılmaktadır.

Bir lider şöyle anlatmaktadır:

Çok sik okul değiştirmek ve yeni okullara gitmek korkunçtu. Bütün çocukluğum boyunca bunu yaptım. Her yeni okul bahçesinde yürürken hayatımın zor olduğunu düşünürdüm. Bunun benim hayatımı belirleyeceğini düşünürdüm. Her defasında okul hatıralarım ve arkadaşlarım kaybolup gittiler. Her gittiğim okulda ilk günlerde gruba dâhil olmak için kendimi onlara tanitmak ve kendimi kabul ettirmek durumunda kaldım; ancak bu mücadele beni geliştirdi. (Kadın Lider 3) 
Bu kadın lider çok farklı okullara gitmek zorunda kalmasını her ne kadar da bir takım zorluklar içerse aslında sosyal ilişkilerinde kendisini geliştiren bir husus olarak değerlendirmektedir. Diğer bir lider:

Benim bütün arkadaşlarım benden daha sâkindiler. Eskiden düzenli olma ve dikkatli olmaya not verilirdi. Benim arkadaşlarım hep 10 alırlardı hâlbuki ben 5-6 alırdım. Rahat duramazdım ve her şeye yorum yapardım. Çocukluğumdan beri ögretmenlere üçâğıt yapardım. Reklamın iyisi kötüsü olmaz, göz önünde olmayı seviyordum ve bu benim için öğreticiydi. (Kadın Lider 7)

Diğer bir lider: "Ben gerçekten çılgın ve canlı bir çocuktum. Daha derin düşündüğümde aslında hoş bir çocuktum; ancak çılgın bir çocuk olduğum için daima çatışmalara sebep oluyordum. Bunun uygun olup olmadığını hep düşünürdüm; ama son sözü söylemeyi hep seviyordum." (Kadın Lider 8).

$\mathrm{Bu}$ iki kadın liderin de diğer arkadaşlarına oranla daha hareketli olduğu ve bir takım davranışlarla öne çıkmaktan hoşlandığı anlaşılmaktadır. Bu öne çıkma ve her zaman öncü olma davranışının liderliklerini güçlendirdiğini düşünmektedirler. Başka bir lider şöyle anlatmaktadır: "Ben çok çocuksuydum. Çocukken okulu, çok katı, disiplini olan bir yer olarak görürdüm ve belki de uyum konusunda hep sorun yaşadım. Itaat etmeyi sevmiyordum." (Kadın Lider 9). Başka bir lider şöyle anlatmaktadır: "Ben de bir tür olay çıkarmaya bağımlıydım ve yönetim bana da bu yüzden çok defalar uzaklaştırma cezası verdi ve babamı arayıp kızın herkesi yoldan çıkarıyor diye şikâyet ettiler; ama uslanmıyordum. Böylece ilişkileri yönlendiriyordum." (Kadın Lider 10). Diğer bir lider: 
Ben okulda çok canliydım. Öğretmenler beni çok severlerdi; ancak yine de bir defasinda ceza vermek durumunda kaldılar; çünkü yasak olan birçok şey yaptım. Her defasında ăgzımı kapatacă̆ıma söz verirdim; ama yine dayanamazdım ve konuşmaya devam ederdim. Aslında yaratıcı fikirlerim vardl; ama okulda kurallarla başım sürekli dertteydi. Kuralları kabul etmek bana zor geliyordu ve birilerinin yönlendireceği birisi değildim. Ben her zaman kendi yolumu kendim çizerdim. (Kadın Lider 11)

Bu üç kadın liderin de otoriteye itaat etmeyle ilgili sorunlar yaşadıkları anlaşılmaktadır. Onlara göre bu durum çoğu zaman başlarını derde soksa da ne yaptıklarını bilen kişiler olarak onların liderlik gelişimine katkı sağlamaktadır.

\section{Diğer bir lider:}

Önceleri değil; ancak sonra fark ettim ki okul ilginç ve önemliymiş. O zamanlar sadece sınıfimı geçmeye bakıyordum; ancak büyüdükçe eğitim ve medenileşmenin önemini anladım. Şimdi eğitimin sosyal statü ve iş durumuyla ilgili önemli bir araç olduğunu görüyorum. Çocukken bu durumu tam olarak anlayamıyordum. (Kadın Lider 6)

Katılımcıların görüşleri genel olarak değerlendirildiğinde, kadın liderlerin çoğunun sosyal anlamda aktif insanlar oldukları ve hatta zaman zaman okula uygun olmadıkları yönünde bir görüşe sâhip oldukları anlaşıılmaktadır. Aslında onların kuralları sevmeyen ve zaman zaman kuralları zorlayan bir yapıya sâhip oldukları görülmektedir. $\mathrm{Bu}$ kuralsız davranışlarına karşın, okul yöneticileri ve öğretmenlerin onlara olumlu yaklaştıkları, onları hep iyi yönde etkilemeye ve teşvik etmeye çabaladıkları anlaşılmaktadır. Zorunlu eğitimden sonra katılımcıların 
büyük bir kısmı genel lise ya da anadolu lisesine giderken yalnızca bir tanesi meslek lisesine devam etmiştir. Katılımcıların görüşlerinden onların zorunlu eğitimden sonraki eğitim sürecinde de hem olumlu hem de olumsuz sosyal ilişkilerinin bulunduğu anlaşılmaktadır. Yine kat1lımcıların iki tanesinin (Kadın Lider 11, Kadın Lider 19) kurallar ve sorumluluklar nedeniyle zor ve zaman zaman sıkıntılı deneyimler geçirmiş oldukları görülmektedir. Hatta katılımcılardan birisi sınıfta nasıl çocuk doğurulduğuna dâir bir gösteri yaptığını ve bu yüzden kınama cezası aldığını belirtmiştir. Diğer bir kadın lider ise sınıfta dans gösterisi yaptığı için okuldan uzaklaştırılma da dâhil kendisini büyük sorunlar içerisinde bulduğunu belirtmiştir. Bütün bunlara rağmen diğer akranlarını yönlendirdikleri ve etkiledikleri diğer bir deyişle ilk liderlik uygulamalarını yaşadıkları sosyal ilişkilerin onların liderlik gelişimleri üzerinde önemli katkılar sağladığı anlaşılmaktadır. Bu anlamda kadın liderlerin sosyal etkinliklere, boş zaman etkinliklerine ve diğer bazı programlara katılımları onlarda olumlu etkilerde bulunmuştur. Hatta iki katılımcı lider bu etkinliklere büyük annesinin etkisiyle katıldığını söylemektedir. Bazı katılımcılar da çocukluklarından bu etkinliklere yatkın olduklarını belirtmektedirler. İki katılımcı, güçlü karakterlerin zıtlıklarından söz etmektedirler ve küçük bir kız öğrenci olarak sosyal ilişkilerde her zaman sorun yaşadıklarını belirtmektedirler.

\section{Kadın Liderlerin Liderlik Gelişimleri Sürecinde Okul Yıllarının Rolü}

Tablo 2'de kadın liderlerin okul yılları ve liderlik gelişimleriyle ilgili ortaya çıkan ana tema ve alt temalara yer verilmiştir. 
Tablo 2. Okul Yılları ve Kadın Liderlerin Liderlik Gelişimleri

\begin{tabular}{|c|c|c|c|}
\hline Ana Tema & Alt Temalar & f & $\%$ \\
\hline \multirow{5}{*}{$\begin{array}{l}\text { Okul Yılları } \\
\text { ve Kadın } \\
\text { Liderlerin } \\
\text { Liderlik } \\
\text { Gelişimleri }\end{array}$} & Akademik başarı & 4 & 20 \\
\hline & Düzenli ders çalışma & 2 & 10 \\
\hline & Rekabetçi olma & 4 & 20 \\
\hline & Okula/Derslere karş1 tutum & 4 & 20 \\
\hline & $\begin{array}{l}\text { Âilenin derslere/okula dair yönlendirmesi ve } \\
\text { desteği }\end{array}$ & 6 & 30 \\
\hline Toplam & & 20 & 100 \\
\hline
\end{tabular}

Araştırmanın bu kısmında okul yıllarının katılımcıların liderlik becerilerinin gelişimine katkısına dâir görüşlere yer verilmiştir. Bu konuda değerlendirme yapan bir kadın lider: "Daima az bir gayretle nispeten iyi notlar almışımdır. Okul yıllarım verimliydi ve bana çok şeyler kattı." (Kadın Lider 1). Diğer bir kadın lider: "Küçükken arkadaşlarıma odaklanırdım okulu öylece bitirdim. Genelde 10 üzerinden 7-8 civarında notlar alırdım. Okulun en iyi öğrencisi değildim; ancak iyiler arasındaydım. Ödevimi yapardım; ama kendimi çok zorlamazdım. Bir gün iş hayatında yönlendiren pozisyonda ve başarıll olacağımı biliyordum." (Kadın Lider 5). Her iki lider de okulda az çalışmalarına rağmen akademik olarak başarılı olduklarını ifade etmektedirler. Bu durum onların akranlarından daha hızlı öğrendiklerini ve olayları daha iyi değerlendirdiklerini göstermektedir. Diğer bir kadın lider: "Okul başarısı söz konusu olduğunda diğer şeyler benim ilgimi daha çok çekmiştir. Sonuç olarak, biraz odaklandiğımda okul kolaydl; ancak dersler dışında ilgilenecek daha zevkli şeyler vardl." (Kadın Lider 4). Başka bir lider: 
Ben parlak bir ögrenci değildim ve bu durum diğer kızlar arasında da yaygın bir durumdu. Bizler 10'luk ögrenciler değildik. Bence ortalama bir ögrrenciydik; ancak şunu söyleyebilirim ki aktif ögrencilerdik. Şüphesiz aktif düşünme ve stratejik düşünme önemlidir; ancak ben her ikisini de birleştirirdim. Bu durum sözde değil eylemde de böyledir. (Kadın Lider 6).

Başka bir lider: "Ben okulda nispeten iyi bir öğrenciydim. Derslerime çalışmak zorundaydım çünkü etrafim çalışkan öğrencilerle doluydu ve en azından onlarla ayn düzeyde olmak istiyordum. Bunun ileriki yıllarda çok faydasını gördüm." (Kadın Lider 7). Bu liderler, okul yıllarında edindikleri akademik bilgilerin onların ileriki yılarında kendi gelişimleri sürecinde katkısı olduğunu ifade etmektedirler. Başka bir lider:

Ailemden iyi notlar almam için baskı görmüyordum. Çocukken yüksek notlar almak için aşırı bir hırsım vardı. Aslında diğerlerinden çok kendimle yarışırdım. İlginç bir durum ve neden kaynaklandı̆̆ını bilmiyorum. Başarı odaklıydım ve yenilgiyi kabul etmiyordum. Bu bende sonraki hayatımda da devam eden bir durum oldu. (Kadın Lider 8)

Diğer bir lider:

Bilgi hayatı tartışılmaz bir şekilde güzeldi. Üniversite zamanı çok ilginç ve şüphesiz hayatı ve dersleri öğrenme arasında bir ritimdi ancak genelde eğlenceliydi. Gerçekten eğitici ve ilginç ve güzeldi. Geriye dönüp baktığımda çoğu zaman mutlu ve huzurlu olduğumu görüyorum. Sizin kendi ögrrenmeniz sinırlıdır. Okulda hayata dâir çok şey öğrendim ve bunlar ayakta kalmama yardım etti. (Kadın Lider 17). 
Diğer bir lider: “Üniversiteye geldiğimde eve gelmiş gibi hissettim. Çocukluğum boyunca okuyordum âilem kızana kadar. Okumayı seviyordum ve halen seviyorum. Üniversiteye gittiğimde, orada istediğim kadar okuyabildiğimi anladım." (Kadın Lider 20). Başka bir lider: "Her şeyle ilgiliydim ve içe kapanık değildim; ancak çok gevezeydim ve âilem daima bana üniversiteye gitmem gerektiğini söylerdi. Üniversite benim kendimi bulmama katkıda bulundu." (Kadın Lider 13). Bu liderler de okul yılları özellikle de üniversite yıllarında elde ettikleri akademik bilgilerin kendileri için önemini vurgulamaktadırlar. Okulun hayata dâir önemli bir birikim sağladığını, bu liderlerin okulda hırslı oldukları ve başarısızlığı da kabul etmedikleri görülmektedir. Diğer bir lider: "Sonra ĕgitimimin yaptı̆̆ım iyi işlerle uyumlu olduğunu anladım." (Kadın Lider 3). Bu lider okul yıllarının hayatın doğrudan kendisiyle ilgili olduğunu ve burada hayatla uyumlu işler yaptığını belirtmesi önemlidir.

Başka bir lider: “Okul geleceğe iyi bir başlangıçtır. Bunu yüksek sesle söyleyebilirim ve daha büyük şeyler yapmak istiyorum. Ancak hangi işin ne olduğunu görebiliyorum ve bu anlamda ilerlemek isteyenlerin üniversiteye gitmeleri gerektiğini söyleyebilirim." (Kadın Lider 19). Diğer bir lider: “Ortaokuldan itibaren yazları yurt dışında geçirdim. Büyükbabam daima bana yol gösterdi. Benim uluslararası, küresel bir bakış kazanmamı istiyorlardı ve bu da beni zenginleştirdi. Oradaki okul yıllarım bana çok şey kattı." (Kadın Lider 9).

Genel olarak bakıldığında kadın liderlerin okul yıllarında özellikle lise yıllarının ilk zamanlarının kendi liderlik gelişiminde etkili 
olduğu anlaşılmaktadır. Katılımcılardan birisi (Kadın Lider 6) ergenlik döneminde sınıfta kalmış, yıllar geçtikçe kadın liderlerin okulla ve derslerle olan ilişkileri yavaş yavaş olumlu yönde değişmeye başlamıştır. Genel olarak iyi bir eğitime sâhip olmaları onların hayatlarında önemli bir rol oynamış ve liderlerin ilgileri zamanla daha çok derslere yönelmiştir. Genel olarak liderlerin okul yılları boyunca öğrenmeye ilgileri ve tutumları olumlu yönde artmıştır. Onlar okul başarısı ile okulun kolaylığının birbiriyle yakından ilişkili olduğunu belirtmektedirler.

Diğer bir yandan kadın liderler, okulda iyi notlar almanın hayatta başarıyı ya da liderliği garanti etmediğini belirtmektedirler. Liderlik eyleme geçme ve diğerlerini eyleme geçirmedir. Bu kapsamda bazı liderler, akademik olarak çok başarılı olmasalar da başka özelliklerin onları lider yaptığının farkındadırlar. Kadın liderlerin başarı ve rekabet için çok çalıştıkları görülmektedir. Onların üniversite eğitimi sürecinde daha çok akademik çalışmalarına odaklandıkları ve uzmanlıklarını güçlendirdikleri görülmektedir.

Kadın liderlerden birisi (Kadın Lider 9) eğitimin iş hayatını olumlu yönde etkilediğini, üniversite eğitiminin sadece geleceğe kap1 açtığını ve bir şey elde etmek için bir araç olduğunu ifade etmektedir. Bazı katılımcılar, üniversite eğitimi boyunca eğitsel etkinliklerin onları doğrudan ve olumu bir şekilde etkilediğini belirtmektedirler. Kadın liderlerin 8 tanesinin üniversite dönemlerinde hem çalışmış hem de öğrenimlerini sürdürmüşlerdir. Kadın liderlerin 5 tanesi ebeveynlerin okul anlamında kullandıkları destekleyici dilin önemi üzerinde dur- 
maktadırlar. Kadın liderler öğrencilik yıllarını tanımlarken 6 tanesi ilkokul yıllarında canlı kişiliklerinin bulunduğunu; ancak yine de bazen öğretmenler ve yöneticilerle çatışmadan kurtulamadıklarını belirtmektedirler.

\section{Tartışma}

Kadın liderlerin sosyal ilişkileri ve okul yıllarının onların liderlik gelişimi üzerindeki rolünü belirlemek amacıyla yürütülen bu çalışmada bazı bulgulara ulaşılmıştır.

Araştırmada elde edilen bulgular kadın liderlerin liderliklerinin ortaya çıkmasında okula ve eğitime dâir olumlu tutum, okul etkinliklerine katılım ve hobilerinin önemli olduğunu göstermektedir. Yine kadın liderlerin, genelde ortalama ya da ortalamanın üzerinde daha çok iyiye yakın öğrenciler oldukları ve derslerden zorlanmadıkları ortaya çıkmıştır. Genel olarak değerlendirildiğinde, okul yıllarının onlar açısından daha kolay geçtiği söylenebilir; ancak diğer bir yandan okul başarısı, yani iyi notlar almış olmanın hayatta ve liderlikte her zaman başarıyı garanti etmediği hususunun altı çizilmektedir.

Bulgular, kadın liderlerin ilkokul yıllarındaki hayatları, onların üniversite ya da iş hayatındaki başarıları konusunda doğrudan bir beklentiye neden olmadığını göstermektedir. Ancak gelişmeyle beraber liderlerin davranışları ve liderlik yapıları onları derslerinde daha başarılı olmaya yöneltmiştir. Katılımcıların büyük bir kısmı üniversite eğitimi boyunca eğitsel etkinliklerin onları doğrudan ve olumu bir şekilde etkilediğini belirtmektedirler. Özetle kadın liderlerin okula dâir olumlu 
tutumlara sâhip olmaları nedeniyle okul yıllarının kadın liderlerin öğrenme ve liderlik gelişimine önemli ölçüde katkıda bulunduğu anlaş1lmaktadır. Bu kapsamda kadın liderler, okul deneyimlerinden ve derslerinden liderlik kariyerlerine yardımcı olan birçok şey öğrenmişlerdir. Yine kadın liderlerin okul yıllarında aktif bireyler olarak farkında olmadan gelecek liderliğe hazırlanmaları ve liderlik becerilerinin gelişmesinde okul yıllarının önemi büyüktür. Bu sonuçlar Murphy ve Johnson (2011), Fine (2010), Matthews (2004), Myers, Slavin ve Southern (1990), Day (2000, 2011), Ropers-Huilman, Carwile ve Barnett (2005), Onay (2014), Mitra (2006), Hyvärinen ve Uusiautti'nin (2014) elde ettikleri bulgularla da benzerlikler göstermektedir. Onlara göre ortaokul dönemlerinde liderlik takımlarını koordine etmek ve topluluk karşısında konuşmak gibi beceriler, liderlik görevleriyle öğrenilir. $\mathrm{Bu}$ araştırmalarda kadın liderlerin okuldan çoklukla hoşlandıkları, okulla ilgili konuşurken bile yüzlerinin güldüğü, gözlerinin 1şıldadığı ve okul yıllarından olumlu bir konuşma tonuyla söz ettikleri üzerinde durulmuştur. Bu kapsamda liderlik gelişiminin eğitimle ilgisi bulunmaktadir.

Genel olarak incelendiğinde örneklemde yer alan kadın liderlerin alanlarında oldukça başarılı çalışmalar yaptıkları ortaya çıkmaktadır. $\mathrm{Bu}$ durum, onların zeki ve işlerine yoğunlaşmış kişiler olabileceklerine dâir bir gösterge olabilir. Kadın liderler, üniversite eğitimleri sayesinde kariyerleri bakımından şüphesiz çok önemli olan zihinsel birikimler ve uzmanlıklar geliştirmişlerdir. Bu kapsamda hiçbir katılımcı üniversite eğitimleriyle ilgili olumsuz bir deneyimden söz etmemiştir. Bu nedenle 
onların üniversite eğitimi süreci yaşamayı ve akademik çalışmaları öğrenme anlamına gelmektedir. İlköğretim ve lise yıllarının aksine üniversite eğitimi sürecinde kadın liderlerin daha çok akademik çalışmalarına odaklandıkları görülmektedir.

Araştırmada elde edilen diğer bir bulguya göre kadın liderlerin sosyal ilişkilerinin onların liderlik gelişimleri üzerinde önemli etkileri bulunmaktadır. Bu sosyal etkinlikler, arkadaş çevresi ve öğretmenleriyle olan ilişkilerin, kadın liderlerin liderliklerinin gelişmesinde önemli olduğu anlaşılmaktadır. Yine katılımcıların genel anlamda lise eğitimi sürecinde yaşadıkları sosyal ilişkilerin üzerinde fazla durmadıkları görülmektedir. $\mathrm{Bu}$ durumun onların lise süreçlerinde sosyal ilişkilerden daha çok üniversiteye hazırlığa odaklanmış olmalarından kaynaklı olabileceği değerlendirilmektedir. Kadın liderler, üniversite öğrenimleri süresince farklı sosyal etkinlikleri kendi gelişimleri için kullanmışlardır. Buna göre, genel olarak kadın liderlerin liderlik pozisyonlarında ilerlemelerinin eğitim ve okul yıllarındaki sosyal kazanımlarıyla ilgili olduğu anlaşılmaktadır. Liderlik eyleme geçme ve diğerlerini eyleme geçirme olarak kabul edildiğinde liderler, akademik olarak çok başarılı olmasalar da sosyal ilişkiler gibi başka özelliklerin onları lider yaptığının farkındadırlar. Bu ilişskiler sürecinde bazı kadın liderlerin başarı ve rekabet için çok çalıştıkları görülmektedir. Kadın liderler gerek okul içinde gerekse de okul dışında birçok sosyal etkinliğe aktif bireyler olarak katılmışlar sorumluluklar üstlenmişlerdir. Liderlerin arkadaşları söz konusu olduğunda, onların arkadaşlarını sosyalleşmenin önemli bir unsuru olarak değerlendirdikleri anlaşıl- 
maktadır. Okula dâir olumlu tutumları, onların okulu arkadaşlarıyla buluştukları sosyalleşmeye yarayan bir yer olarak algılamaları da bu durumu desteklemektedir. Onlara göre sosyal ilişkilerin önemi, okulun ilk yıllarında başlayarak hayat boyu arkadaşlığa dönüşebilmesi nedeniyledir. Bu sonuçlar bazı çalışmalarda elde edilen bulgularla benzerlik göstermektedir (Antonio, 2001; Berscheid, 2006; Charbonneau ve Nicol, 2002; Dasgupta ve Asgari, 2004; Fine, 2010; Graen ve Uhl-Bien, 1995; Hoppe ve Reinelt, 2010; Hyvärinen ve Uusiautti, 2014; Mayhew, Wolniak ve Pascarella, 2008; Matthews, 2004; Murphy ve Johnson, 2011; Snyder ve Lopez, 2002; Uhl-Bien, 2006; Ross, 2015). Onlara göre kadın liderler sosyal çevrelerinden ve akademik çevreleri olan okullardan liderlik gelişimleri süresince olumlu yönde etkilenmişlerdir.

Bazı katılımcılar girişimciliklerini, etkinlikleri nasıl plânladıklarını ve diğerlerini bunlara nasıl katmaya çalıştıklarını belirtmişlerdir. Yine onlar yaratıcılıklarını ayrıntılı bir şekilde ifade etmektedirler. $\mathrm{Bu}$ kapsamda onların çocukluklarından itibaren gruplarını yönlendiren ve etkileyen bir pozisyonda oldukları anlaşılmaktadır. Ancak diğer bir yandan bazı kadın liderler (1 katılımcı) olumsuz sosyal ilişkilerden söz etmektedirler. Bu katılımcı âilesinin işi dolayısıyla sık sık okul değiştirmek zorunda kaldığını ve sosyal çevresinin de buna bağlı olarak sürekli değiştiğini belirtmektedir. Söz konusu katılımcı değişen bu sosyal ortamlardan hoşnut olmadığını; çünkü her gittiği yerde yeni sosyal çevre bulmasının kolay olmadığını ifade etmektedir. Ancak yine de bunun bile kendisini geliştirdiğine inanmaktadır. Kadın liderlerden birisi eğitimin iş hayatını etkilediğini diğer bir kadın lider ise üniversite 
eğitiminin sadece geleceğe kapı açtığını ve bir şey elde etmek için bir araç olduğunu ifade etmektedir. $\mathrm{Bu}$ anlamda kadın liderlerin sosyal etkinliklere, boş zaman etkinliklerine ve diğer bazı programlara kat1lımları onlarda olumlu etkilerde bulunmuştur.

\section{Sonuç}

Sosyal ilişkilerin ve okul yıllarının kadın liderlerin liderlik gelişimleri üzerindeki rolünü belirlemek amacıyla yürütülen bu çalışmanın sonuçlarından birisi, okul yıllarının başında kadın yöneticilerin sosyal ilişkilerinin önemli olduğu, okulda katıldıkları etkinlikler başta olmak üzere, okul deneyimlerinin liderlik gelişimleri üzerinde çok olumlu etkilerde bulunduğudur. Daha sonraki okul yıllarındaki anlatılarından, özellikle üniversite eğitiminin katıldıkları sosyal ilişkiler ve gruplarda elde ettikleri kazanımlar nedeniyle liderlik gelişimlerinde büyük oranda etkili olduğu anlaşılmaktadır. Bu kapsamda kadın yöneticilerin iş hayatı deneyimleri söz konusu olunca daha buyurucu bir dil kullandıkları görülmektedir.

Araştırmanın diğer bir sonucuna göre, okul yılları kadın yöneticilerin geleceklerini aydınlatmıştır. $\mathrm{Bu}$ bulgu kadın liderlerin okul yıllarının liderlik gelişiminde çok önemli olduğunu göstermektedir. $\mathrm{Bu}$ durum onların okulda herhangi bir güçlükle karşılaşmadıkları anlamına gelmemektedir; ancak görüşmelerde bunların önemli durumlar olarak öne çıkmadığ 1 görülmektedir. Bu anlamda okulun çocuklukta "yegâne sığınılacak yuva” olarak görüldüğü düşünülürse, bireyin yeteneklerinin gelişmesinde ve bu özelliklerini anlamasında önemli bir yeri bulunmaktadır. Murphy ve Johnson'a göre (2011) eğitim, sosyal katılım, 
etkinlikler, spor ve yetiştirme konularında bireylerin erken öğrenme deneyimleri önemli bir başlangıç sağlamaktadır. Teorik bilgi, çocukluk ve gençlikte bir tür sıçrama tahtası anlamına gelmektedir. Bu anlamda, her geçen gün daha fazla çocuk ilgilendiği için okulda ya da okul d1şında etkinliklerin liderlik gelişiminde özel olarak araştırılması gerekmektedir (Saloniemi, Salonen, Lipiäinen, Nummi ve Virtanen, 2013). Ancak dersler ile iş hayatı arasındaki dengeyi kurmak aynı zamanda kültürel bir zorunluluktur. Örneğin, üniversite hayatının genç yaşlarda başladığı birçok ülkede öğrenci erken mezun olduğu için iş hayatına da erken başlamaktadır. Bu da onların daha düşük bir seviyeyle hayata başladıklarını göstermektedir (Lindberg, 2009).

Araştırmada elde edilen diğer bir sonuca göre kadın liderler, öğrencilik yıllarında akademik olarak ortalama ya da ortalamanın üzerinde bir seviyededirler. $\mathrm{Bu}$ anlamda okul, öğretim, öğretmenler ve akranlar liderlik için önemli bir uygulama fırsatı sunmaktadır. Sonraki liderlik gelişimi, çocukluk dönemlerindeki durumu ve eğitimle ilgilidir (Hyvärinen ve Uusiautti, 2014). Liderliğin aslında diğerlerini harekete geçirmek olduğu düşünüldüğünde liderlik, kişilik özellikleri ve okul deneyimlerinden olumlu anlamda etkilenmektedir. Sonuç olarak okul yılları ve sosyal ilişkilerin kadın liderlerin öğrenme ve liderlik gelişimine önemli ölçüde katkıda bulunduğunu anlaşılmaktadır. Bu araştırma sonucunda uygulayıcılar ve diğer araştırmacılar bazı öneriler geliştirilmiştir: 
$\checkmark \mathrm{Bu}$ araştırma nitel olarak sınırlı sayıda bir grupla yürütülmüştür. Nicel ve nitel olarak yürütülecek başka bir çalışma ile çok sayıda kadın liderin bu konudaki görüşlerine ulaşılabilir.

$\checkmark$ Eğitim yönetiminin değişik alanlarında kadın liderlerin sayısı yeterli değildir. $\mathrm{Bu}$ durum, okul yıllarında düzenlenecek olan değişik etkinliklerle öğrencilerin liderlik potansiyellerini geliştirmelerine olanak sağlayacak şekilde düzenlenmelidir.

$\checkmark$ Daha çok bir “erkek mesleği” olarak algılanan eğitim yöneticiliğinde kadın liderlerin gelişiminde etkili olan akademik ve sosyal alanların desteklenmesi sağlanabilir.

\section{Kaynakça}

Alvesson, M. ve Billing, Y. D. (1997). Understanding gender and organizations. London: Sage.

Antonio, A. L. (2001). The role of interracial interaction in the development of leadership skills and cultural knowledge and understanding. Research in Higher Education, 42(5), 593-617.

Arıkan, G. ve Yıldırım, Ş. (1993). Amerikan toplumunda kadınların yönetim kadrolarında yer alma koşulları. Hacettepe Üniversitesi Edebiyat Fakültesi Dergisi, 10(2), 45-53.

Aydın, İ. (2009). Türk eğitim yönetiminde öncü kadınlar-1. Ankara: Pegem Akademi.

Bailey, K. D. (1994). Methods of social research (4. bask1). New York: The Free Press.

Barker, R. (1999). Social work dictionary. Washington, DC: NASW. 
Başaran, İ. E. (1992). Yönetimde insan ilişkileri. Ankara: Kadığlu Matbaas1.

Berscheid, E. (2006). A human being's greatest strength: other people.

L. G. Aspinwall ve U. M. Staudinger, (Eds.), A psychology of human strengths içinde (47-56). Helsinki: Edita.

Bogdan, R. C. ve Biklen, S. K. (2003). Qualitative research for education: an introduction to theories and methods (4. bask1). New York: Pearson Education.

Bosak, J. ve Sczesny, S. (2011). Exploring the dynamics of incongruent beliefs about women and leaders. British Journal of Management, 22(2), 254-269.

Boydak, M. ve Akpınar, B. (2002). Okul yönetiminde kadın yöneticilerin başarısı. Fırat Üniversitesi Sosyal Bilimler Dergisi, 12(2), 219-234.

Büyüköztürk, Ş., Kılıç-Çakmak, E., Akgün, Ö. E., Karadeniz, Ş. ve Demirel, F. (2008). Bilimsel araştırma yöntemleri. Ankara: Pegem A Yayıncılık.

Cavanagh, F. R. ve Romanoski, J. T. (2006). Development of a model of school principal behaviours: Rasch model and structural equation model analyses of teacher observations. (Rapor No.2145), Australian Research Council.

Charbonneau, D. ve Nicol, A. A. M. (2002). Emotional intelligence and leadership in adolescents. Personality and Individual Differences, 33(7), 1101-1113.

Creswell, J. W. (2002). Educational research: planning, conducting, and evaluating quantitative and, qualitative research. Upper Saddle Creek, NJ: Pearson Education. 
Çelikten, M. (2004).Okul müdürü koltuğundaki kadınlar: Kayseri ili örneği. Erciyes Üniversitesi Sosyal Bilimler Enstitüsü Dergisi, 17(2), 91-118.

Çiçek Sağlam, A. ve Bostanc1, A. B. (2012). Milli Eğitim Bakanlığı merkez ve taşra örgütleri yönetim pozisyonlarinda kadinlarin temsil edilme düzeyine yönelik yönetici görüşleri. Uşak Üniversitesi Sosyal Bilimler Dergisi, 5(2), 140-155.

Dasgupta, N. ve Asgari, S. (2004). Seeing is believing: Exposure to counterstereotypic women leaders and its effect on the malleability of automatic gender stereotyping. Journal of Experimental Social Psychology, 40(5), 642-658.

Davidson, M. J. ve Burke, R. J. (2004). Women in management worldwide: Facts, figures and analysis-An overview. R. J. Burke ve M. J. Davidson, (Eds.), Women in management worldwide: Facts, figures and analysis içinde (1-15). Aldershot: Ashgate Publishing.

Day, D. (2000). Leadership development: A review in context. The Leadership Quarterly, 11(4), 581-613. doi: 10.1016/S1048-9843(00)00061-8.

Day, D. (2011). Integrative perspectives on longitudinal investigations of leader development: From childhood through adulthood. The Leadership Quarterly, 22(3), 561-571. doi: 10.1016/j.leaqua.2011.04.012.

Denzin, N. K. ve Lincoln, Y. S. (2005). The sage handbook of qualitative research (3. bask1). Sage, Thousand Oak.

Dhuey, E. ve Lipscomb, S. (2008). What makes a leader? Relative age and high school leadership. Economics of Education Review, 27(2), 173-183. 
Dominici, F., Fried, L. P. ve Zeger, S. L. (2009). So few women leaders it's no longer a pipeline problem, so what are the root causes? Academe Online.

http://csuw3.csuohio.edu/engineering/IDEAL/New\%20Folder/S o_few_women_leaders.pdf.

Eagly, A. H. ve Johnson, B. T. (1990). Gender and leadership style: A meta-analysis. Psychological Bulletin, 108(2), 233-256.

Ekonen, M. (2007). Manifold careers: Narrative research on female leaders' career development. Lic. thesis, University of Jyväskylä, Finland.

Ergin, A. ve Çınkır, Ş. (2005). Eğitim yönetiminde kadınlar. Eğitim araştırmaları. Eurasian Journal of Educational Research. Anı Yayıncılık, 18, 84-96.

Fine, M. (2010). Revolutionizing education: Youth participatory action research in motion. New York and London: Routhlegde, Taylor \& Francis Group.

Gidengil, E. ve Everitt, J. (2003). Talking though: Gender and reported speech in campaign news coverage. Political Communication, 20, 209-232.

doi:10.1080/10584600390218869.

Glaser, B. G. (1992). Theoretical sensitivity: advances in the methodology of grounded theory. Mill Valley, Ca: Sociology Press.

Gümüşeli, A. İ. (1996). İlköğretim okulu müdürlerinin öğretim liderliği davranışlarına ilişkin araştırma (İstanbul ili örneği). Yayımlanmamış doktora tezi, Yıldız Teknik Üniversitesi.

Graen, G. B. ve Uhl-Bien, M. (1995). Relationship-based approach to leadership: development of leader-member exchange (LMX) 
theory of leadership over 25 years: Applying a multi-level multi-domain perspective. Leadership Quarterly, 6(2), 219-247.

Gündüz, H. B. ve Doğan, A. (2009, Mayıs). Okul yöneticilerinin liderlik stilleri ve yaraticilik düzeyleri. 1. Uluslararası Eğitim Araştırmaları Kongresi, Çanakkale.

Hacıfazlıŏlu, Ö. (2010). Yükseköğretimde lider olarak göreve uyum sağlama süreci: Türkiye ve Amerika'dan kadın liderlerin deneyimleri. Kuram ve Uygulamada Eğitim Bilimleri, 10(4), 2221-2273.

Hoobler, J. M., Wayne, S. J. ve Lemmon, G. (2009). Bosses' perceptions of family-work conflict and women's promotability: Glass ceiling effects. Academy of Management Journal, 52(5), 939-957.

Hoppe, B. ve Reinelt, C. (2010). Social network analysis and the evaluation of leadership networks. The Leadership Quarterly, 21(4), 600-619.

Huy, Q. N. (2001). In praise of middle managers. Harvard Business Review, 79(8), 72-79.

Hyvärinen, S. ve Uusiautti, S. (2014). Safe and encouraging home providing the countdown to leadership? Finnish female leaders' childhood memories. Early Child Development and Care. doi: 10.1080/03004430.2013.876626.

Juuti, P. (2010). Special features of Finnish leadership. P. Juuti, (Ed.), Leadership as resource: From change to success içinde (13-28). Helsinki: JTO.

Kerkhof, van de M. (2006). The repertory grid technique, (RGT), integrated assessment.

http://www.ivm.vu.nl/en/Images/PT4_tcm53-161509.pdf. 
Kim, Y. ve Baylor, L. A. (2006). A social-cognitive framework for pedagogical agents as learning companions. Educational Technology Research and Development, 54(6), 569-596.

Kuusela, S. (2010). Power and interaction in leadership. Yayımlanmamış doktora tezi, University of Tampere.

Lindberg, M. (2009). Study times and transition to worklife: perspective to policy discourse and research offered by comparative research. Tiedepolitiikka, 34, 27-33.

Lombardo, M. M. ve McCall, M. W. Jr. (1978). Leadership. M. W. McCall Jr. ve M. M. Lombardo, (Eds.), Leadership: where else can we go? içinde (1-12). Durham, NC: Duke University.

Lord, R. G. ve Hall, R. J. (2005). Identity, deep structure and the development of leadership skill. The Leadership Quarterly, 16(4), 591-615.

Marlene, G. F. (2009). Women Leaders' Discursive Constructions of Leadership. Women's Studies in Communication, 32(2), 180-202. doi: 10.1080/07491409.2009.10162386.

Marshall, C. ve Rosman, B. G. (2006). Designing qualitative research (4. bask1). Thousand Oak: Sage.

Martelius-Louniala, T. (2003). Emotions and female leaders. A.-M. Lämsä, (Ed.), Perspectives on female leadership içinde (47-71). Jyväskylä: University of Jyväskylä.

Matthews, M. S. (2004). Leadership education for gifted and talented youth: A review of the literature. Journal for the Education of the Gifted, 28, 77-113. doi: $10.1177 / 016235320402800105$. 
Mayhew, M. J., Wolniak, G. C. ve Pascarella, E. T. (2008). How educational practices affect the development of life-long learning orientations in traditionally-aged undergraduate students. Research in Higher Education, 49(4), 337-356.

Mayring, P. (2000). Qualitative content analysis. Forum: Qualitative Social Research, 1(2), 1-10.

http://www.qualitative-research.net/index.php/fqs/article/view/1 089/2385.

McCall, M. W. Jr., Lombardo, M. M. ve Morrison, A. M. (1988). The lessons of experience: how successful executives develop on the job. Lexington, MA: Lexington Books.

MEB. (2015). Millî Ĕ̆itim İstatistikleri Örgün Eğitim 2015-2016. http://sgb.meb.gov.tr/www/icerik_goruntule.php?KNO=232.

Miles, M. B. ve Huberman, M. A. (1994). An expanded sourcebook qualitative data analysis. London: Sage.

Mitra, D. (2006). Increasing student voice and moving toward youth leadership. The Prevention Researcher, 13, 7-10.

Mozhgan, A., Parivash, J., Nadergholi, G. ve Jowkar, B. (2011). Student leadership competencies development. Procedia: Social and Behavioral Sciences, 15, 1616-1620.

Doi: 10.1016/j.sbspro.2011.03.340.

Murphy, S. E. ve Johnson, S. K. (2011). The benefits of a long-lens approach to leader development: Understanding the seeds of leadership, The Leadership Quarterly, 22(3), 459-470. doi: 10.1016/j.leaqua.2011.04.004.

Myers, M. M., Slavin, M. C. ve Southern, W. T. (1990). Emergence and maintenance of leadership among gifted students in group problem solving. Roeper Review, 12(4), 256-261. 
doi:10.1080/02783199009553287.

Nidiffer, J. (2001). Crumbs from the boy's table. The first century of coeducation. J. Nidiffer ve C. T. Bashaw, (Eds.), Women administrators in higher education içinde (13-34). New York: State University of New York Press.

Northouse, P. G. (2013). Leadership: Theory and practice (6. bask1). Thousand Oaks, CA: Sage.

Onay, M. (2014). Kadın ve erkek yöneticilerin liderlik davranışları arasındaki farklılıklar. Organizasyon ve Yönetim Bilimleri Dergisi, 6(2), 73-85.

Özdemir, S. (21 Haziran 2013). Lider öğretmenleri nasıl yetiştirmeliyiz? Kamudan Haber.

http://www.kamudanhaber.com/lider-ogretmenleri-nasil-yetistir meliyiz-makale, 1938.html adresinden edinilmiştir.

Peele, G. (2005). Leadership and politics: A case for a closer relationship? Leadership, 1(2), 187-204.

doi: $10.1177 / 1742715005051858$.

Porat, K. L. (1991). Women in administration: The difference is positive. Clearing House, 64(6), 412-415.

Quinn, R. E. (1988). Beyond rational management: mastering paradoxes and competing demands of high effectiveness. San Francisco: Jossey-Bass.

Ropers-Huilman, B., Carwile, L. ve Barnett, K. (2005). Student activists' characterizations of administrators in higher education: Perceptions of power in the system. The Review of Higher Education, 28(3), 295-312. 
Ross, S. (2015). The road to self-leadership development: Busting out of your comfort zone. USA: Emerald Group Publishing Limited.

Rouleau, L. ve Balogun, J. (2011). Middle managers, strategic sensemaking, and discursive competence. Journal of Management Studies, 48(5), 953-983.

Saloniemi, A., Salonen, J., Lipiäinen, L., Nummi, T. ve Virtanen, P. (2014). Haning many irons in the fire: Finnish female leaders' school memories. Journal of Education and Learning, 3(2), 1-13.

Schneider, B., Paul, M. C., White, S. S. ve Holcombe, K. M. (1999). Understanding high school student leaders, I: Predicting teacher ratings of leader behavior. The Leadership Quarterly, 10(4), 609-636.

Snyder, C. R. ve Lopez, S. J. (2002). The future of positive psychology. A declaration of independence. C. R. Snyder ve S. J. Lopez, (Eds.), Handbook of positive psychology içinde (751-767). Oxford: Oxford University Press.

Solheim, B. O. (2000). On top of the world: women's political leadership in Scandinavia and beyond. Westport, CN: Greenwood.

Syväjärvi, A. ve Vakkala, H. (2012). Psychological leadership orientation-the meaning of positivity in people management. J. Perttula ve A. Syväjärvi, (Eds.), Psychology of leadership-People management in changing working life içinde (195-226). Jyväskylä: PS-kustannus.

Tan, M. (2002). Eğitim yönetiminde kadınlara yer var mı? C. Elma ve Ş. Çınkır (Eds.), 21. Yüzyıl Eğitim Yöneticilerinin Yetiştirilmesi Seтроzуити içinde (37-49). Ankara: Ankara Üniversitesi. 
Thompson, A. (2003). Special series on girls and women in education caring in context: four feminist theories on gender and education. Curriculum Inquiry, 33(1), 9-65.

Turan, S. ve Ebiçlioğlu, N. (2002). A study of gender differences and leadership characteristic of elementary school principals. Kuram ve Uygulamada Ĕ̈itim Yönetimi, 31, 444-445.

Uhl-Bien, M. (2006). Relational leadership theory: Exploring the social processes of leadership and organizing. The Leadership Quarterly, 17(6), 654-676.

Usluer, L. (2000). Kadın öğretmenlerin yönetici konumlara yükseltilmeme nedenleri konusundaki öğretmen ve yönetici görüşlerinin değerlendirilmesi. Yayımlanmamış doktora tezi, Ankara Üniversitesi.

Uusiautti, S. ve Määttä, K. (2013a). How to promote the healthy development of human resources in children and youngsters? European Journal of Academic Research, 1(5), 212-221.

Uusiautti, S. ve Määttä, K. (2013b). Significant trends in the development of Finnish teacher training education programs (1860-2010). Education Policy Analysis Archives, 21(59), 1-22.

Uusiautti, S., Syväjärvi, A., Stenvall, J., Perttula, J. ve Määttä, K. (2012). It's more like a growth process than a bunch of answers, University leaders describe themselves as leaders, Procedia-Social and Behavioral Sciences, 69, 828-837. doi: 10.1016/j.sbspro.2012.12.005.

Vanhala, S. (2007). Women as leaders in Finland, Women and leadership.

http://www.jyu.fi/economics/naisjohtajuus/Naiset\%20ja\%20joht ajuus\% 20oppimateriaali.pdf adresinden edinilmiştir. 
Vanhala, S. (2011). Career orientations of women middle managers. L. Husu, F. Hearn, A.-M. Lämsä ve S. Vanhala, (Eds.), Women, management and leadership-Naiset ja johtajuus içinde (30-37). Helsinki: Edita.

Vinnicombe, S. (2000). The position of women in management in Europe. J. B. Ronald ve M. J. Davidson, (Eds.), Women in management. Current research issues içinde (9-25). London: Sage.

Wilson, B. (1995). Metaphors for instruction: Why we talk about learning environments. Educational Technology, 35(5), 25-30.

Yıldırım, A. ve Şimşek, H. (2003). Sosyal bilimlerde nitel araştırma yöntemleri. Ankara: Seçkin Yayıncılık.

Yukl, G. (2010). Leadership in organizations. Upper Saddle River, NJ: Prentice-Hall.

Zacharatos, A., Barling, J. ve Kelloway, E. K. (2000). Development and effects of transformational leadership in adolescents. The Leadership Quarterly, 11(2), 221-226.

Zeldin, S. ve Petrokubi, J. (2006). Understanding innovation: Youth-adult partnerships in decision making. The Prevention Researcher, 13(1), 11-14. 